\title{
Long-Term Monitoring of Montane MeAdow BIODIVERSITY IN THE GREATER YELLOWSTONE ECOSYSTEM
}

\author{
DIANE DEBINSKI $\downarrow$ DEPARTMENT OF ANIMAL ECOLOGY \\ IOWA STATE UNIVERSITY $\downarrow$ AMES \\ KELLY KINDSCHER \ KANSAS BIOLOGICAL SURVEY \\ UNIVERSITY OF KANSAS \\ LAWRENCE
}

\section{$\uparrow \quad$ ABSTRACT}

This research project is part of an ongoing biodiversity inventory and monitoring effort that began in 1992. It involves using intensive, local field sampling to test for relationships between species distribution patterns and remotely sensed data. We have been using a time series of satellite multispectral imagery for monitoring the extent, condition, and spatial pattern of montane meadows on a seasonal and interannual time scale. Spectrally-based, spatiallyexplicit models have been developed for six meadow types along a hydrological gradient. Statistically significant relationships were found between remotely sensed data and a large number of plant and animal species in the Greater Yellowstone Ecosystem (GYE). We have shown that mesic meadows (meadows intermediate in the hydrological gradient) are the sites of highest plant species diversity and the sites of highest seasonal and interannual change. Our research during 2001 was specifically targeted to continue monitoring the plant and animal communities of the GYE with the goal of developing a list of indicator species and their present year-to-year variation. The rarity and low abundances of some of the species have limited our understanding of these patterns to the most common species. Thus, additional data will allow us to expand upon our understanding of these groups as indicators.
\end{abstract}

We believe that these communities and their associated species may be some of the best indicators of environmental change in the GYE.

\section{$\uparrow \quad$ INTRODUCTION}

In 1992, we initiated an interdisciplinary project in collaboration with geographer Mark Jakubauskas entitled "Modeling Spatial and Temporal Dynamics of Montane Meadows and Biodiversity in the Greater Yellowstone Ecosystem." Our research team has been developing predictive species assemblage models based upon landscape level habitat analysis (e.g., Debinski and Humphrey, 1997; Debinski et al., 1999; 2000; Kindscher et al., 1998; Jakubauskas et al., 1998; Jakubauskas and Debinski, 1995). The goal was to use intensive, local field sampling to extrapolate species distribution patterns within a region. The hypothesis was that plant and animal locations could be predicted by analyzing spectral reflectance characteristics as recorded by satellite multispectral scanners. This research was originally conducted in the northwest corner of the Greater Yellowstone Ecosystem (GYE) and then expanded to the Grand Teton National Park in 1996. Grants from the U.S. Forest Service, the U.S. Park Service, the U.S. Environmental Protection Agency, and three universities have supported our work. 
Our previous research showed that montane meadow communities can function as early indicators of environmental change because they are highly sensitive to variations in precipitation and temperature (Debinski et al. 1999; 2000; Kindscher et al., 1998; Jakubauskas et al., 1998;). We have continued our surveys of the plant, bird and butterfly taxa to allow us to quantify the year-to-year variation in species abundances and distribution patterns. These data are critical if we hope to differentiate between natural background fluctuations and real changes caused by climate change.

Our sampling sites were identified using remotely sensed classification of the montane meadow habitats. Six meadow types were identified using a GIS to stratify the study area by topography and geology. Field sampling was used to collect data on the distribution of plant, bird, and butterfly species. We sampled extensively for four summers (1997-2000) in two regions of the ecosystem: the northern region (hereafter termed the Gallatin study area) included the Gallatin National Forest and northwestern portion of Yellowstone National Park; the southern region (hereafter termed Teton study area) included Grand Teton National Park. These two regions are $192 \mathrm{~km}$ apart, but have very similar plant and animal communities. Twenty-five sample sites were located in the Tetons (Figure 1) and thirty sample sites were located in the Gallatins during 1997 (Figure 2). These were termed "core sites" and were sampled during each of the four years. Additional sites were added in later years (including up to 65 sites per region), but we have focused the efforts of this project on these core sites. We also used a time series of satellite multispectral imagery ( 3 images per year during the growing season) for monitoring the extent, condition, and spatial pattern of montane meadows on a seasonal and interannual time scale.

Landsat Thematic Mapper data were used to identify a moisture gradient in montane meadows of the Greater Yellowstone Ecosystem (Jakubauskas and Debinski, 1995; Debinski, 1994). Six meadow types were defined, ranging from extremely hydric (M1) to extremely xeric (M6) meadows. Field investigations confirmed the moisture gradient predicted for the meadows (Debinski et al., 2000, Jakubauskas et al., 1998; Kindscher et al. 1998). M1 and M2 meadows are willow (Salix spp.) thickets and sedge (Carex spp.) marshes respectively with some standing water. M3 meadows are characterized by high forb diversity and were located near streams. M4 meadows are of medium moisture with cinquefoil (Potentilla spp.) and mixed herbaceous vegetation, while M5 meadows have a mixture of sagebrush (Artemesia tridentata) and herbaceous vegetation. M6 meadows are characteristically xeric, rocky, and dominated by sagebrush.

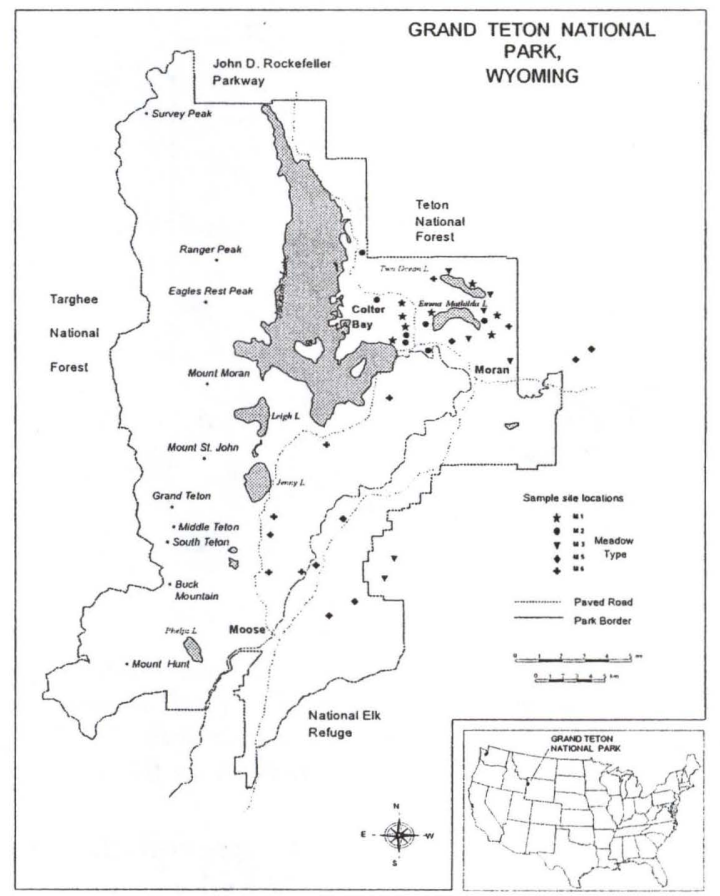

Figure 1. Core sampling sites in Teton region including Grand Teton National Park and a few sites just beyond the Park border. Twentyfive sample sites were located in the Tetons during 1997-2001, five of each of the five meadow types (M1-M3, M5-M6). No M4 meadows exist in the Teton region.

\section{Species Characterization in Sample Sites}

Our sample sites are stratified by region (Gallatins and Tetons) and meadow type (two regions, six meadow types in Gallatins and five meadow types in Tetons, five replicates for a total of 55 "core" sites). Sample plots are currently marked with rebar stakes and are re-flagged each season. Plant data were collected in July from 20 by $20 \mathrm{~m}$ plots at all sample sites. Bird data were collected as we have done during each of the past four years, from early June to mid-July (when most songbirds stop singing). Butterfly data were collected from mid-June to mid-August. Collection earlier than these dates is prohibited by cold weather. Birds and butterflies were surveyed two times per season at each of these sites during the summer of 2001. Data collection in each of the two regions alternates every two weeks to ensure that species with phenologically different emergence times or activity periods are included in both data sets. 


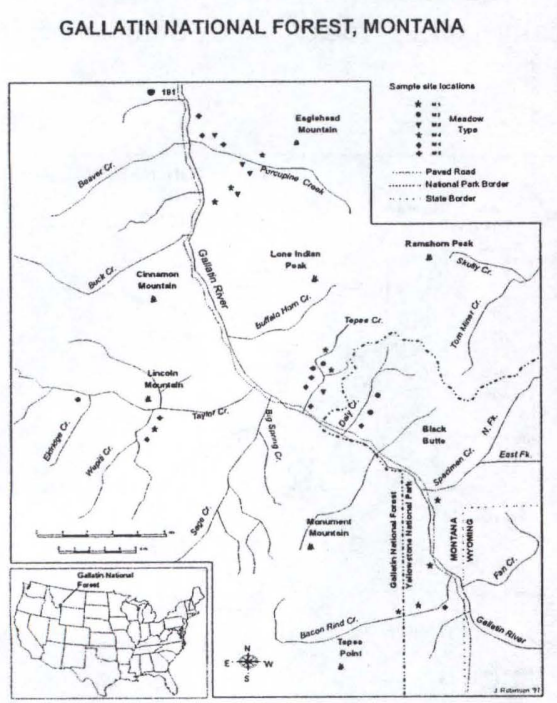

Figure 2. Core sampling sites in the Gallatin study area including the Gallatin National Forest and northwestern portion of Yellowstone National Park. Thirty core sampling sites were located in the Gallatins during 1997-2001, five of each of the six meadow types (M1-M6).

At each site plant cover data were collected by identifying e ach species in the field and assigning a percent cover value. For each species where identification was difficult to determine, a plant voucher was collected and brought back to the University of Kansas herbarium for help in making an accurate determination.

Abundance data were collected for butterflies and birds in each of the sampling sites. Birds were surveyed between $0530-1030 \mathrm{hrs}$ using point counts in $100 \mathrm{~m}$ diameter circular plots. Two observers were present for each 15 min survey. One point count was conducted at each site. Butterflies were surveyed between 0930-1630 hrs by two people netting for 20 minutes in $50 \times 50 \mathrm{~m}$ plots at each sampling site. Surveys were limited to times when temperature is above 70 degrees $\mathrm{F}$, wind is less than $16 \mathrm{~km} / \mathrm{hr}$, and clouds do not obscure the sun. Each butterfly was placed in a glassine envelope with a time of capture noted on the envelope. At the end of the survey, all individuals of each species were tallied and released unless a voucher was needed to confirm species identity. Butterfly voucher specimens are archived with Dr. Debinski's entomological collection at ISU.

\section{Research Products}

- Diane Debinski and James Pritchard finished their manuscript "A Complete Guide to Butterflies of the Greater Yellowstone Ecosystem" to be published by Roberts Rinehart Publishers in 2002.

- Diane Debinski collaborated with Dr. Paul Opler, author of the Peterson's Guide to Butterflies, to create a current list of butterflies of Grand Teton National Park. This list is linked to the Northern Prairie Biological Resources database on biodiversity across North America http://www npwrc.usgs.gov/ resource/taxa I.htm. Debinski's(1993), "Butterflies of Glacier National Park, Montana" is also available on that web page. The Northern Prairie Wildlife Research Center, which is part of the U.S. Geological Survey located in Jamestown, North Dakota is compiling biodiversity data nationwide for this web page.

- We are finalizing a publication that summarizes the comparison of our biodiversity assessment techniques to that of the Wyoming and Montana GAP analysis work ( $\mathrm{Su}$ et al., unpublished manuscript).

- A paper on predicting the occurrence of plant species in montane meadows from remotely sensed data was presented at the Third International Conference on Geospatial Information in Agriculture and Forestry in Denver, Colorado, 5-7 November 2001. Citation: Peterson, D. L., Jakubauskas, M.E., Kindscher, K., and Debinski, D. 2001. Hyperspectral remote sensing of nonforested montane vegetation communities. The 3rd International Forestry and Agriculture Remote Sensing Conference and Exhibition, Denver, November 2001.

\section{Summary \& Future Directions}

The goal of this research is to continue monitoring of long-term, well-established biodiversity inventory \& montoring sites in the GYE. Our research has shown that spectral reflectance patterns are a function of vegetation community type. We have also found that many animal species are statistically correlated with spectrally-based meadow habitat types. We have developed models for predicting several of the most abundant bird species relative to meadow type 
(Saveraid et al., 2001). Butterfly species also show strong associations with particular meadow types, especially in the Teton region (Debinski et al., in press). Although we have found strong relationships between habitat type and species distribution, the rarity of many of the species requires long-term data collection to uncover some of the larger patterns. During 2002, we will conduct analyses of species distribution that will include four years of data for birds, butterflies, and plants in our core sampling areas. These additional data will allow us to expand upon our understanding of these groups, and the analysis of these data will allow us to refine our list of indicators.

Finally, we have noticed that the abundances of many of the willow-dependent songbirds vary significantly between the Gallatin and Teton sampling areas. During the summer of 2002, we will expand the songbird research to begin to examine potential interactive effects of habitat type, vegetation structure, and landscape context on local abundance and distribution of birds in montane meadows.

\section{$\downarrow$ ACKNOWLEDGMENTS}

Funding for this research was provided by the Grand Teton Natural History Association, the Nature Conservancy's Smith Fellowship Program, and the Iowa Agriculture and Home Economics Experiment Station. Field assistance was provided by A. Hetrick, C. Frazer, T. Aschenbach, S. Ashworth, H. Loring, J. Hanlon, and others.

\section{$\downarrow$ Literature Cited}

Debinski, D.M. 1993. Butterflies of Glacier Park, Montana. Occasional Papers of the Museum of Natural History 159:1-13.

Debinski, D.M. 1994. A remote sensing and GIS-based model of habitat as a predictor of biodiversity. 17th Annual Report 1993, University of Wyoming National Park Service Research Center, Laramie, Wyoming, pp. 117-124.

Debinski, D.M. and P. Humphrey. 1997. An integrated approach to biological diversity assessment. Natural Areas Journal 17: 355365.
Debinski, D.M., M.E. Jakubauskas, and K. Kindscher. 1999. A remote sensing and GIS-based model of habitats and biodiversity in the Greater Yellowstone Ecosystem. International Journal of Remote Sensing 20:3281-3292.

Debinski, D.M., M.E. Jakubauskas, and K. Kindscher. 2000. Montane meadows as indicators of environmental change. Environmental Monitoring and Assessment. 64:213-225.

Debinski, D.M., M.E. Jakubauskas, K. Kindscher, E.H. Saveraid and M. Borgognone. (in press). Predicting meadow communities and species occurrences in the Greater Yellowstone Ecosystem. In Predicting Species Occurrences: Issues of Scale and Accuracy (Scott, J. M., P. J. Heglund, M. Morrison, M. Raphael, J. Haufler, B. Wall, editors). Island Press. Covello, CA.

Jakubauskas, M.E., and D.M. Debinski. 1995. An integrated spectral and ecological approach to mapping forest and meadow communities of the Greater Yellowstone Ecosystem. Abstracts, 1995 Association of American Geographers Annual Meeting, Chicago, Illinois.

Jakubauskas, M.E., K. Kindscher, and D.M. Debinski. 1998. Multitemporal characterization and mapping of montane sagebrush communities using Indian IRS LISS-II imagery. Geocarto International 13:65-74.

Kindscher, K., A. Fraser, M.E. Jakubauskas, and D.M. Debinski. 1998. Identifying wetland meadows in Grand Teton National Park using remote sensing and average wetland values. Wetlands Ecology and Management 5:265273.

Saveraid, E.H., D.M. Debinski, K. Kindscher, and M.E. Jakubauskas. 2001. A comparison of satellite data and landscape variables in predicting bird species occurrences in the Greater Yellowstone Ecosystem. Landscape Ecology 16(1):71-83.

Su, Jeffrey C., Debinski, D.M., M.E. Jakubauskas, and K. Kindscher. (unpublished manuscript). Testing three scales of remotely sensed habitat classifications as coarse-filters for biodiversity conservation. 